\title{
КЛАСТЕРИЗАЦІЯ ЯК НАПРЯМ ДИВЕРСИФІКАЦІЇ РОЗВИТКУ СІЛЬСЬКИХ ТЕРИТОРІЙ В УМОВАХ ДЕЦЕНТРАЛІЗАЦІЇ
}

\author{
Хомюк Наталія Леонідівна \\ кандидат економічних наук, докторант \\ Східноєвропейського національного університету імені Лесі Українки(м.Луцьк, Україна) \\ ORCID0000-0002-2516-2968 \\ nataliabilous@gmail.com
}

У статті охарактеризовано процес кластеризації як напрям диверсифікації розвитку сільських територій в умовах децентралізації. З'ясовано, що диверсифрікація форм власності та господарювання на сільських територіях передбачає стимулювання розвитку різних форм власності та господарювання, створення кооперативів і кластерів. Розкрито сутність категорії «кластер» та «агропромисловий кластер». Зроблено висновки, що важливе значення при реформуванні місцевого самоврядування в Україні має розвиток аграрних кластерів, який сприяє створенню нових робочих місць, розвитку виробничої та соціальної інфрраструктури на сільських територіях, утворенню об'єднань підприємств із замкненим циклом виробництва готової продукції, зниженню собівартості та ціни сільськогосподарських товарів, підвищенню якості вирощеної продукції, підвищенню конкурентоспроможності учасників агропромислового кластера за рахунок впровадження інноваційних технологій та доступу агропромислової продукції до регіональних та світових ринків. Визначено вплив кластеризації на розвиток сільських територій в Україні. Висвітлено переваги та основні етапи створення агропромислових кластерів. Досліджено світовий досвід та досвід України у створенні кластерів. Визначено фрактори, які негативно впливають на розвиток кластерів в Україні. Доведено, що перехід на кластерну систему сприятиме підвищенню конкурентоспроможності сільських територій та розвитку різних галузей економіки.

Ключові слова: кластер, сільська територія, кластеризація, агропромисловий кластер, децентралізація, диверсифрікація розвитку сільських територій.

DOI: https://doi.org/10.32845/bsnau.2019.2.15

Постановка проблеми. Процес децентралізації та створення об'єднаних територіальних громад є основою диверсифікованого розвитку сільських територій, зокрема у сфері перебудови відносин між центральними та місцевими органами влади [1]. Окрім того, уже понад два десятиліття в Україні здійснюється реформування земельних відносин. За цей час було проведено ліквідацію монополії державної власності на землю, роздержавлення і приватизацію земель сільськогосподарського та іншого призначення та створено нормативно-правові передумови для розвитку різних форм господарювання на землі. Проте наявні сільськогосподарські структури змінюються без врахування реалій сьогодення. Тому в процесі реалізації реформи місцевого самоврядування виникає проблема урізноманітнення сільськогосподарської та несільськогосподарської діяльності на сільських територіях.

В Україні аграрний сектор є найбільш капіталомістким та трудомістким виробництвом внаслідок несвоєчасної модернізації обладнання та неефективному управлінні сільськогосподарськими організаціями. Як показує світовий досвід, одним з інструментів відродження та забезпечення розвитку сільськогосподарського виробництва $€$ кластеризація, тобто створення та розвиток аграрних кластерів, які сприяють розвитку виробничої та соціальної інфраструктури на сільських територіях та створенню робочих місць.

Аналіз останніх досліджень і публікацій. Дослідженням проблем розвитку сільських територій приділено увагу таких вчених, як В. Бойко, В. Борщевський, Т. Гоголь, О. Гуторова, Ю. Губені, В. Дієсперов, І. Кульчій, А. Ключник, М. Лесів, М. Й. Малік, Л. Мармуль, О. І. Павлов, Х. М. Притула, М. А. Хвесик, В. Юрчишин та багато інших. Питання розвитку процесів кластеризації та формування агарних кластерів знайшли своє відображення у працях вітчизняних та зарубіжних науковців, серед яких: М. Портер, П.Саблук, М.Кропивко,
В.Павлов, С.Соколенко. В Україні перехід до кластерного управління започаткований, проте ще не набув належного розвитку і популярності. Тому виникла об'єктивна необхідність у дослідженні цієї проблеми.

Метою статті $є$ характеристика процесу кластеризації як напряму диверсифікації розвитку сільських територій в умовах децентралізації.

Відповідно до цієї мети завданнями статті є:

- розкрити сутність категорій «кластер» та «кластеризація»;

- визначити вплив кластеризації на розвиток сільських територій;

- висвітлити переваги та основні етапи створення кластерів;

- дослідити світовий досвід та досвід України у створенні кластерів;

- охарактеризувати фактори, які гальмують розвиток кластерів в Україні.

Основні результати дослідження. Головна проблема сільських жителів полягає в тому, що їх фрінансове становище більш складне, ніж у міського населення. Про низький рівень життя сільських мешканців України свідчить такий показник, як частка населення із середньодушовими еквівалентними грошовими доходами на місяць нижче законодавчо встановленого прожиткового мінімуму: якщо загалом по Україні у 2017 р. вона становила 6,8 \%, то у сільській місцевості - 10,2\%. Частка населення із середньодушовими еквівалентними грошовими доходами на місяць нижче фактичного прожиткового мінімуму по Україні у 2017 р. становила 49,0 \%, а у сільській місцевості - 57,6 \% [2, с. 83]. У сільській місцевості на 1 січня 2018 року проживало 3690 тис. пенсіонерів, або 31,5\% з кількості тих, які перебували на обліку в органах Пенсійного фонду України [2, с. 35]. Як бачимо, сільські території характеризуються значними проблемами розвитку, тому потребують пошуку новітніх підходів до забезпечення сталого та 
диверсифікованого розвитку, а кластеризація виступає одним із таких підходів.

Ми погоджуємось 3 думкою Т.Козира, що стратегічною метою розвитку сільської території є забезпечення можливості громадян задовольнити свої запити та потреби на території своєї громади, не виїжджаючи за її межі, або виїжджаючи на короткий час, тобто без зміни місця постійного проживання [3]. Адже як фактор економічного зростання людські ресурси слід розглядати як працівників, що мають певні професійні знання та навички, які можуть бути використані для розвитку територій, на яких вони проживають. При залученні сільського населення у виробництво на території громади відповідно знизиться рівень безробіття, зростуть доходи домогосподарств, і паралельно збільшаться надходження до місцевих бюджетів за рахунок податку на доходи фрізичних осіб [4].

Як зазначає О. Гуторов, децентралізація для сільських територій передбачає процес розширення й зміцнення їх прав та повноважень при одночасному звуженні прав і повноважень відповідних центральних органів управління з метою оптимізації та підвищення ефрективності управління суспільно важливими справами, найповнішої реалізації місцевих інтересів [5].

У системі розвитку сільських територій та країни в цілому важливу роль відіграють територіальні громади як найважливіші її елементи. В ході моніторингу процесу децентралізації виявлено, що за 2015 - 2018 роки лише 37 \% від загальної кількості територіальних громад об'єдналися, що спричинено нестачею висококваліфікованих кадрів та небажанням багатших уже сформованих громад приєднувати до себе бідніші територіальні громади.

Забезпечення диверсифікованого розвитку сільських територій повинно ґрунтуватися на засадах єдності й цілісності, врахуванні процесу децентралізація, який здійснюється шляхом формування громад (це дозволить жителям села приймати участь в управлінні громадою), з обов'язковим врахуванням географрічних, економічних, екологічних, етнічних та демографрічних особливостей кожного сільського територіального утворення.

Під диверсифікацією розвитку сільських територій в умовах децентралізації пропонуємо розглядати комплекс заходів, спрямованих на урізноманітнення сільськогосподарської та несільськогосподарської діяльності на сільських територіях, розширення джерел фінансування програм сільського розвитку та заходів, організованих об'єднаними територіальними громадами та трансформацію форм власності та господарювання з метою розширення сфер зайнятості та доходів сільського населення на основі інтегрованого підходу й через реалізацію процедур інформаційного забезпечення (стратегічна екологічна оцінка, експертні оцінки завдяки процедурам моніторингу соціо-еколого-економічних показників) [6].

На нашу думку, диверсифікація форм власності та господарювання на сільських територіях передбачає стимулювання розвитку різних форм власності та господарювання, створення кооперативів і кластерів.

Важливе значення при реформуванні місцевого самоврядування в Україні має розвиток кластерів, який сприяє створенню нових робочих місць, розвитку виробничої та соціальної інфрраструктури на сільських територіях, утворенню об'єднань підприємств із замкненим циклом виробництва готової продукції, зниженню собівартості та ціни сільськогосподарських та несільськогосподарських товарів, підвищенню якості вирощеної та випущеної продукції, підвищенню конкурентоспроможності учасників кластера за рахунок впровадження інноваційних технологій та доступу продукції до регіональних та світових ринків.

Термін «кластер» з англійської мови перекладається як гроно, скупчення, група, пучок, жмуток і використовується в різних галузях науки. У фізиці кластер трактується як система з великої кількості слабо пов'язаних атомів або молекул, в музиці означає співзвуччя, утворене малими або великими секундами [7, с. 544]. Одним із засновників досліджень економічних питань формування та діяльності кластерів $€$ Майкл Портер, який вважає, що кластер - це група географічно сусідніх взаємозв'язаних компаній і пов'язаних з ними організацій, які діють у певній сфері, що характеризуються спільністю діяльності й взаємодоповнюють одна одну [8, с. 258]. Також він вважає, що чим більш розвинені кластери в окремій країні, тим більш вищі в ній рівень життя населення та конкурентоспроможність економіки. Слід зазначити, що економічний кластер не є юридичною особою.

Вважається, що в організаційному плані краще, щоб утворення кластера відбувалося «знизу», від зацікавлених організацій, а органи влади лише допомагали у становленню кластера. Гірше, коли ініціатором створення кластера будуть органи влади, тоді, враховуючий гіркий досвід колективізації, учасники будуть протидіяти об'єднанню [9].

Щоб створити кластер на сільській території, необхідно пройти певні етапи, серед яких: формування ідеї створення кластера (необхідно визначити потребу в кластері, вивчити місце і сферу економіки, якої він стосується); встановлення ділових відносин між організаціями; згуртування технологічно пов'язаних підприємств; залучення тих учасників кластера, які займалися б просуванням виробленої продукції; залучення інноваційної, суспільної та фінансової інфраструктур; ефективне використання економічного та природного середовищ; укладення договорів між учасниками кластерів про співпрацю.

Кластери можуть складатись із декількох компаній або із великої кількості підприємств, іноді їх чисельність сягає семи тисяч учасників. Такі утворення мають неоднакову ступінь взаємодії між фрірмами, які до них входять. Кластери утворюються не тільки в умовах розвиненої економіки держав, а й в тих країнах, які ще розвиваються. Вони формуються на національному та регіональному рінях. Одна з основних особливостей кластерів перед іншими формами організації виробництва $€$ те, що увага звертається не на окремі галузі, а на зв'язок між ними.

Кластер є відносно новим інструментом підвищення конкурентоспроможності країни та каталізатором розвитку її специфічних галузей. Він є ефективним засобом швидкого піднесення економіки тому, що використовує природні та історичні особливості регіону. Одна з головних задач у системі підвищення конкурентоспроможності сільських територій це виявити потенціал їх кластеризації.

Досвід країн ЄС показує, що кластеризація є однією з умов підвищення конкурентоспроможності економіки регіону та держави в цілому. В ЄС процес кластеризації почався зі створення в 1968 році Генерального директорату з регіональної політики. Пізніше у 1975 році було сфрормовано Європейський фонд регіонального розвитку, а у 1988 році Європарламентом була прийнята Хартія регіоналізму і почала функціонувати Рада регіональних та місцевих об'єднань. В 2000 
році на саміті в Лісабоні було створено Європейський дослідницький простір. А 21 січня 2008 році в Стокгольмі було схвалено Європейський кластерний меморандум [10].

Аналіз досвіду розвинутих країн світу свідчить, що найбільше кластерних структур формується у Данії, Великобританії, Канаді, Німеччині, Італії, США, Австрії. Наприклад, У Данії найбільш розповсюджені кластери з виробництва молочних продуктів, у Великобританії - з виробництва сільськогосподарської продукції та надання фінансових послуг, в Італії - з виробництва меблів, одягу. Можна зробити висновок, що кластери утворюються в різних сферах економіки - у сільському господарстві, промисловості, металургії.

Світовий досвід демонструє такі переваги виробничих систем, створених на основі кластерної моделі: збільшення інвестицій в економіку регіону; використання інноваційних технологій; створення нових робочих місць; зниження витрат на виробництво продукції; підвищення конкурентоспроможності компаній регіону; зниження ціни готової продукції; ефективніше використання місцевих природних ресурсів; вихід товару не тільки на регіональні ринки, а й світові.

Україні слід залучати світовий досвід розвитку кластерів і підтримувати кластерні ініціативи на сільських територіях.

Оскільки аграрна галузь є фундаментом стабільної економіки, наповнення бюджетів та простором для залучення інвестицій, тому необхідно за допомогою підтримки держави та об'єднаних територіальних громад забезпечити підвищення продуктивності агровиробництва. Але не можна вважати, що сільським господарством займається більшість сільського населення. Сільська територія - це не лише місце життєдіяльності людей та просторовий базис виробництва, а й природне середовище. Тому на процес розвитку сільських територій впливають природні умови та природні ресурси, географічне положення, етнічний склад населення, стан економіки та ін. Врахування сучасних тенденцій розвитку сільських територій в Україні повинно бути покладено в основу розробки та реалізації стратегії диверсифікації розвитку цих територій, одним з напрямів якої є стимулювання кластеризації.

П.Т.Саблук та М.Ф.Кропивко під агропромисловою кластеризацією розуміє концентрацію та спеціалізацію агропромислового виробництва з формуванням на території замкнутих продуктивних ланцюгів «виробництво, зберігання, переробка та реалізація сільськогосподарської продукції» на засадах інтеграції для одержання учасниками кластерів конкурентоспроможної продукції й підвищення прибутковості [9].

Для успішної діяльності агропромислового кластера необхідні, крім бажання досягти певних вигод шляхом об'єднання інтересів підприємств, ще й відповідні умови щодо наявності землі. Важливою також $є$ наявність ефективної інфраструктури всіх рівнів, в тому числі аграрного ринку; дієвість банківських установ, які покликані забезпечити високий рівень фінансової дисципліни, кредитування учасників; наявність державних програм розвитку та підтримки кластерів; присутність наукових та освітніх інституцій, які б здійснили підготовку висококваліфікованих кадрів [11].

Ф.А. Важинський та О.С. Молнар зазначають, що при формуванні кластера в агропромисловому виробництві, доцільно виділити пріоритетні напрями його розвитку, що сприятиме найповнішому використанню реальних і потенційних переваг регіону. Враховуючи наявні переваги, такими галузями можуть стати зерновиробництво, вирощування олійних культур, овочівництво. Великий виробничий потенціал становлять тваринницькі галузі - м'ясне та молочне скотарство, свинарство, птахівництво [12].

Кластери, або, інакше кажучи, розташовані у безпосередній близькості та організаційно об'єднані кінцеві виробники сільськогосподарської сировини, харчової продукції, постачальники необхідних матеріальних ресурсів та послуг, навчальні та науково-дослідні установи, дослідницькі лабораторії та інші суб'єкти господарювання, є важливими рушійними факторами сталого розвитку регіональної економіки [13].

Але відсутність нормативно-правового регламентування створення кластерної організації виробництва та відсутність визначення поняття «кластер» у вітчизняному законодавстві унеможливлює утворення та розвиток кластерів у різних галузях економіки, в т.ч. й сільському господарстві. Наприклад, ще в 2008 році Міністерством економіки України розроблений проект «Концепції створення кластерів в Україні», але він так і не був затверджений. У діючій Постанові Кабінету Міністрів «Про схвалення Стратегії розвитку аграрного сектору економіки на період до 2020 року» [14] серед основних принципів розвитку аграрного сектору у сфері формування та реалізації державної аграрної політики є орієнтація на підтримку розвитку кооперації із застосуванням кластерної моделі.

Згідно Концепції Кабінету Міністрів України щодо Загальнодержавної цільової економічної програми розвитку промисловості на період до 2020 року (Розпорядження № 603-р від 17 липня 2013 р.) передбачається визначення на законодавчому рівні поняття «кластеризація» та порядку фінансування кластерів. Проте у стратегіях розвитку регіонів України до основних напрямків реформування економіки відносять формування та розвиток кластерів. Наприклад, у внесених змінах у 2012 році до «Стратегії розвитку Волинської області на період до 2020 року» йдеться про укладення угоди про створення міжнародного туристичного кластера та спільної промоції бренду «Полісся» та серед основних завдань щодо стимулювання розвитку малого та середнього бізнесу $є$ створення IT кластеру [15].

Варто наголосити, що, аграрний сектор та сільські території $€$ пріоритетним напрямком розвитку економіки України та Волинської області зокрема. За інформацією Світового центру даних з геоінформатики та сталого розвитку Міжнародною радою з науки, Комітетом із системного аналізу при НААНУ, НТУУ «Київський політехнічний інститут ім. Сікорського» розроблено форсайт та побудову стратегії соціально-економічного розвитку України на середньостроковому (до 2020 року) і довгостроковому (до 2030 року) часових горизонтах. Головним кластером майбутньої економіки України $є$ аграрний сектор, відповідно саме агросектор принесе найбільший внесок у зростання економіки (19-24 відсотки) за умови його модернізації. Нині розроблено Проект Закону України «Про основні засади державної аграрної політики та державної політики сільського розвитку» [19, с. 38-39].

В.о. Міністра аграрної політики та продовольства України Ольга Трофімцева зазначає, що створення кластерів це оптимальний інструмент розвитку сільських територій. Їх ефективність залежить від ініціативи бізнесу різних секторів економіки. Адже об'єднання фрінансових, людських та природних ресурсів, держави, бізнесу та сільських громад володіє значним потенціалом для підвищення конкурентоспроможно- 
сті регіонів. На даний час діють пілотні проекти з впровадження агрокластерів на Львівщині («ГорбоГори») та Одещині («Фрумушика Нова»). Їх загальні бюджети становлять відповідно 27,6 та 39,56 млн грн. Метою агрокластеру «ГорбоГори» $є$ відродження західного українського села на принципах децентралізації із застосуванням кластерних механізмів розвитку, як ланцюгів доданої вартості; а агроекокластеру «Фрумушика Нова» - збереження місцевої екосистеми, розвитку сільського туризму та екологічного сільгоспвиробництва [16].

Співпраця бізнесу, влади і громади - основа розвитку будь-якої території, в тому числі сільської, але в кластері вона більш розгалужена. I це дає змогу виграти всім. Завдяки об'єднанню зусиль можна вирішувати проблеми розвитку туризму і громади в цілому. До того ж туристичний кластер - це і додаткові робочі місця, і підвищення іміджу території, і інвестиційна привабливість, і розвиток території та поповнення бюджетів. I навіть розвиток нових спеціалізацій у навчальних закладах. Адже з розвитком кластерів виникає необхідність, наприклад, у кластерному менеджері. В Україні реалізовується проект «Туристичні кластери $300+»$, який заснований на принципах ефективної соціальної взаємодії. Мета даного проекту - це створення понад 300 кластерів і всієї інфраструктури для їх ефективної діяльності. Наприклад, в певному регіоні, де всі зацікавлені в тому, щоб до них їхав турист, об'єднуються і за допомогою експертів, створюють сучасний, цікавий туристичний продукт високої якості, безпечний і доступний для споживачів [17].

Географрічне розташування та природно-кліматичні умови, наявність трудового потенціалу, спеціалізація суб'єктів господарювання Волинської області дають можливість виділити такі кластерні системи, які мають перспективи розвитку на сільських територіях: агропромисловий та турис- тичний кластери. Загальна територія Волинської області становить 2014,4 тис. га (3,3 \% від всієї площі України), з яких 1047,5 тис. га (52,0 \%) це землі сільськогосподарського призначення. Структура сільськогосподарських угідь регіону зображено на рис. 1.

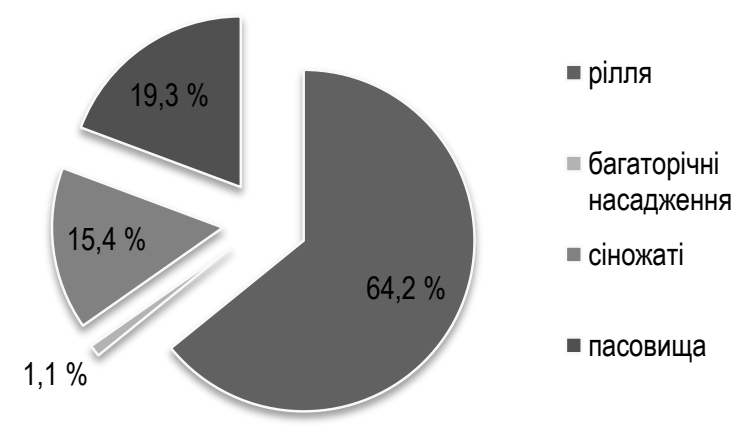

Рис. 1. Структура сільськогосподарських угідь Волинської області станом на 1 січня 2018 року

Джерело: побудовано за даними Державної служби України з питань геодезії, картографії та кадастру [18].

Найбільш поширеними у Волинській області є сільськогосподарські підприємства з розміром площ сільськогосподарських угідь від 20 до 50 га (135 одиниць) (рис. 2), в яких сконцентровано 4616 га, що дає можливість для формування агрокластерів з метою реалізації вирощеної продукції та виходу на світові ринки. Значні площі сільськогосподарських угідь (80904 га) знаходяться у користуванні 11 агроформувань. У структурі посівних площ сільськогосподарських культу в усіх категоріях господарств переважають зернові та зернобобові культури (51,5\%). Кормові культури становлять $15,4 \%$, картопля та овочеві культури - 15,3\%, а технічні $17,8 \%$.

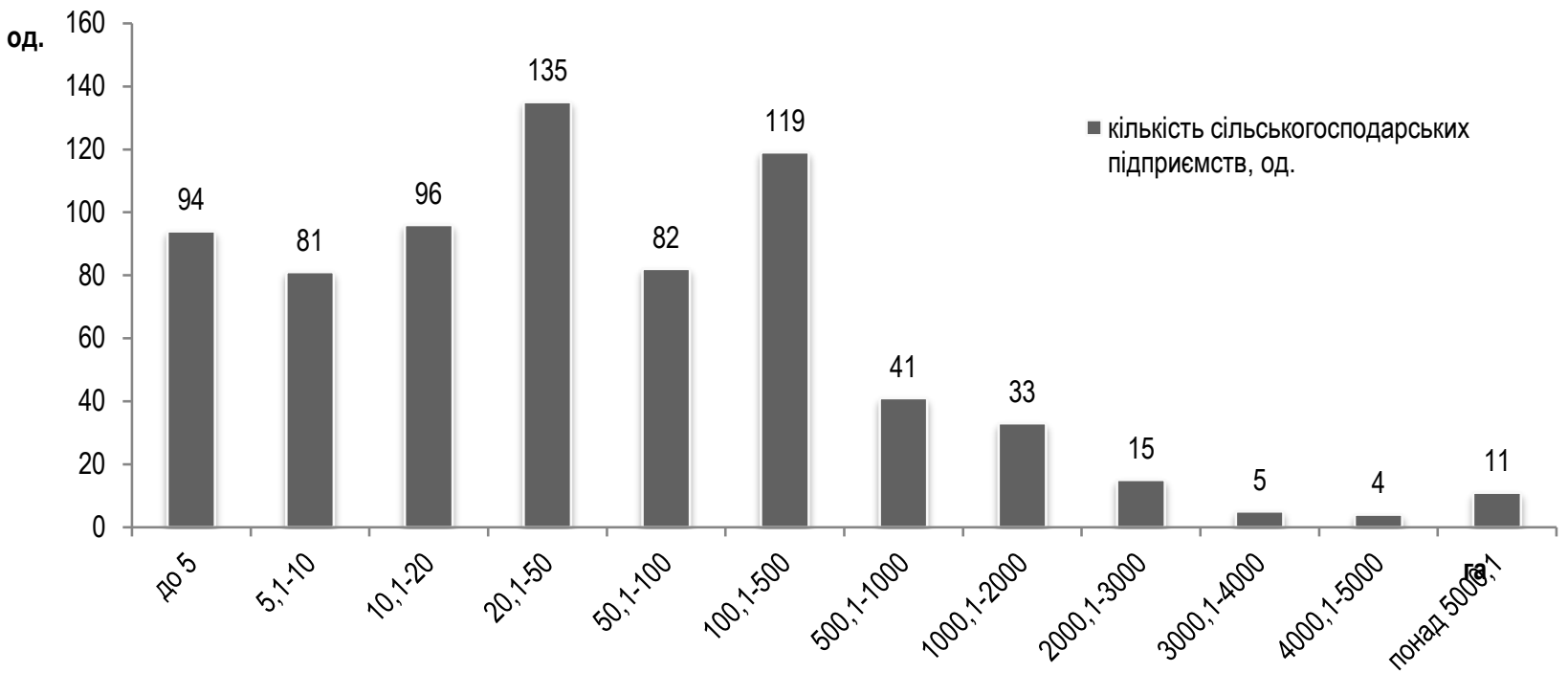

Рисунок 2. Розподіл сільськогосподарських підприємств Волині за розміром сільськогосподарських угідь у 2017 році Джерело: побудовано авторами на основі [19, с. 56].

Основні соціально-економічні показники Волинської області свідчать про аграрно-промислове спрямування економіки досліджуваного регіону. Питома вага Волині у загальнодержавному виробництві продукції сільського господарства у 2017 р. становила 2,8 \%, у т.ч. продукції рослинництва
- 2,3 \%; продукції тваринництва - 3,9 \% [19, с. 5].

Проте Л. Черчик наголошує на тому, що Волинська область має потенціал і щодо розвитку санаторно-курортного лікування (Ківерцівський, Ковельський, Шацький райони), туристично-екскурсійного просрілю (Володимир-Волинський, 
Горохівський, Луцький та Шацький райони) та оздоровлення і відпочинку (всі райони, окрім Камінь-Каширського, Любешівського та Маневицького) [20, с. 14]. Це свідчить про можливість створення туристичного кластеру на територій Волинської області в рамках реалізації проекту «Туристичні кластери $300+»$.

Висновки. Можна стверджувати, що реформування місцевого самоврядування - це складний процес, який здійснює вплив на розвиток сільських об'єднаних територіальних громад, оскільки наближає процеси управління та прийняття рішень до громадськості; сприяє самостійності у формуванні доходів і видатків бюджету та надає можливість сільським жителям отримувати якісні адміністративні, соціальні та інші послуги. В умовах децентралізації влади об'єднані територіальні громади на Львівщині та Одещині вже створили туристичні кластери «ГорбоГори» та «Фрумушика Нова», що розвитку даних сільських територій та їх диверсиффікації. Сільські території Волинської області також мають потенціал щодо створення агропромислових та туристичних кластерів.

Проаналізувавши наукову літературу, можна зробити висновок, що основними факторами, які гальмують розвиток кластерів в Україні є: відсутність в законодавчих актах України визначення поняття «кластер», «кластеризація»; обмеженість у залученні іноземних інвестицій; недостатня державна фінансова підтримка розвитку кластерних систем; недостатній рівень етичності ведення бізнесу та відсутність довіри між органами влади та фрірмами; низькій рівень співпраці між науковими інститутами і кластерами з метою використання інноваційних проектів; відсутність єдиної інформаційної бази про існування кластерів в Україні. Перехід на кластерну систему сприятиме підвищенню конкурентоспроможності сільських територій та розвитку різних галузей економіки, в тому числі й агропромислового комплексу.

\section{Cnuсок літератури:}

1. Хомюк Н.Л. Децентралізація як чинник диверсифікації розвитку сільських територій. Економічний часопис Східноєвропейського національного університету імені Лесі Українки. Луцьк : Вежа-Друк, 2019. № 1 (17). С. 85-91.

2. Статистичний щорічник України за 2017 рік / за ред. І. Є. Вернера. К. Державна служба статистики України, 2018. $541 \mathrm{c}$.

3. Козир Т.О. Практичні аспекти стратегічного планування розвитку сільських територій. Теорія та практика державного управління. 2009. Вип. 3 (26). С. 307-314.

4. Хомюк Н.Л. Сучасні тенденції розвитку сільських територій в Україні. Економіка та розвиток. 2019. № 1 (1). С. 85-92.

5. Гуторов О.І. Розвиток сільських територій в умовах децентралізації. Глобальні та національні проблеми економіки. 2014. Вип. 2. С. $820-823$.

6. Хомюк Н.Л. Диверсифікація розвитку сільських територій як економічна категорія. Організаційно-економічні засади інформаційного забезпечення економіки: колективна монографія. Рівне : НУВГП, 2018. С. $232-242$.

$1728 \mathrm{c}$.

7. Великий тлумачний словник сучасної української мови / уклад. і гол.ред. В.Т.Бусел. К: Ірпінь: ВТФ Перун, 2005.

8. Портер М. Конкуренція [пер. с англ.]. М.: Издательский дом «Вильямс», 2005. 608 с.

9. Саблук П.Т., Кропивко П.Т. Кластеризація як механізм підвищення конкурентоспроможності та соціальної спрямованості аграрної економіки. Економіка АПК. 2010. № 1. С. 3-12.

10. The European Cluster Memorandum. URL: www.clusterodservatory.

11. Вишневська О.М., Наумова О.М. Теоретичні аспекти і практичні особливості розвитку кластерних структур аграрного сектора економіки у контексті підвищення конкурентоспроможності. Збірник наукових праць Харківського національного аграрного університету. Економічні науки. 2013. №5. С. 28-33.

12. Важинський Ф. А., Молнар О. С. Кластеризація - фактор конкурентоспроможного виробничо-господарського потенціалу та ефективного розвитку сільських територій. Соціально-економічні проблеми сучасного періоду України. 2013. Вип. 6(104). C.175-181.

13. Самофратова В. А. Процес кластеризації як базис сталого розвитку агропродовольчої сфрери регіону. Інтернаука. Серія: Економічні науки. 2017. № 3 (3). С. 69-72.

14. Про схвалення Стратегії розвитку аграрного сектору економіки на період до 2020 року: Розпорядження Кабінету Міністрів України від 17.10.2013 № 806-p. URL: https://zakon.rada.gov.ua/laws/show/806-2013-\%D1\%80

15. Про Стратегію розвитку Волинської області на період до 2020 року: Рішення Волинської обласної ради від 20.03.2015 №34/7. URL: http://volynrada.gov.ua/session/34/7-0

16. Розвиток сільських територій: Трофімцева покладає надії на кластери. Сайт: Landlord. URL: https:/llandlord.ua/news/dymka/rozvytok-silskykh-terytorii-trofimtseva-pokladaie-nadii-na-klastery/

17. Офіційний державний сайт України «Децентралізація». Туристичний кластер задля розвитку громади. URL: https://decentralization.gov.ua/news/9751

18. Державна служба України з питань геодезії, картографії та кадастру: офіц. веб-сайт: україн. версія. URL: http://land.gov.ua

19. Стратегічні пріоритети соціально-економічного розвитку сільських територій Волинської області в умовах євроінтеграції : колективна монограсрія / А.О. Соколова, Л.Ф. Петриканин, Л.В. Сичук та ін. Луцьк : Надстир'я, 2018. 152 с.

20. Сучасний стан розвитку туристично-рекреаційного комплексу Волинської області: монографія / Черчик Л., Єрко І., Коленда Н., Міщенко О. Луцьк. 2014. 154 с. 
Khomiuk N. L., PhD, postdoc, Lesya Ukrainka Eastern European National University (Lutsk, Ukraine)

Clusterization as a direction of diversification of rural development in terms of decentralization

The article describes the process of clustering as a direction of diversification of rural development in terms of decentralization. It is found that the diversification of ownership and management in rural areas implies stimulating the development of different forms of ownership and management, creating cooperatives and clusters. The essence of the category "cluster" and "agro-industrial cluster" is revealed. It is concluded that the development of agrarian clusters is important for the reform of local self-government in Ukraine, which contributes to the creation of new jobs, the development of industrial and social infrastructure in rural areas, the formation of associations of enterprises with a closed cycle of production of finished products, reducing the cost and cost of agriculture products, improving the quality of grown products, increasing the competitiveness of participants in the agro-industrial cluster through the introduction of innovative technology agricultural products and access to regional and global markets. The influence of clustering on rural development in Ukraine has been determined. The advantages and main stages of creation of agro-industrial clusters are highlighted. The world experience and experience of Ukraine in creating clusters is investigated. The factors that negatively influence the development of clusters in Ukraine are identified. It is proved that the transition to a cluster system will help to increase the competitiveness of rural areas and the development of various sectors of the economy.

Keywords: cluster, rural territory, clustering, agro-industrial cluster, decentralization, diversification of rural development.

Дата надходження до редакції: 05.02.2019 р. 